\title{
Impact of Ozonisation Time and Dose on Health Related and Microbiological Properties of Rapanui Tomatoes
}

\author{
Anna Onopiuk*D, Arkadiusz Szpicer, Iwona Wojtasik-Kalinowska, Agnieszka Wierzbicka and Andrzej Półtorak
}

Department of Technique and Food Development, Institute of Human Nutrition Sciences, Warsaw University of Life Sciences, Nowoursynowska 159c Street, 32, 02-776 Warsaw, Poland; arkadiusz_szpicer@sggw.edu.pl (A.S.); iwona_wojtasik_kalinowska@sggw.edu.pl (I.W.-K.); agnieszka_wierzbicka@sggw.edu.pl (A.W.); andrzej_poltorak@sggw.edu.pl (A.P.)

* Correspondence: anna_onopiuk@sggw.edu.pl

Citation: Onopiuk, A.; Szpicer, A.; Wojtasik-Kalinowska, I.; Wierzbicka, A.; Półtorak, A. Impact of Ozonisation Time and Dose on Health Related and Microbiological Properties of Rapanui Tomatoes. Agriculture 2021, 11, 428. https://doi.org/10.3390/ agriculture11050428

Academic Editor: María Gloria Lobo

Received: 7 March 2021

Accepted: 26 April 2021

Published: 10 May 2021

Publisher's Note: MDPI stays neutral with regard to jurisdictional claims in published maps and institutional affiliations.

Copyright: (C) 2021 by the authors Licensee MDPI, Basel, Switzerland. This article is an open access article distributed under the terms and conditions of the Creative Commons Attribution (CC BY) license (https:// creativecommons.org/licenses/by/ $4.0 /)$.

\begin{abstract}
The impact of ozone concentration and ozonisation time on the selected chemical, physical and microbiological properties of Rapanui tomatoes was investigated. Tomatoes were exposed to gaseous ozone at concentrations of 0.9 and $2.5 \mathrm{mg} \mathrm{L}^{-1}\left(\mathrm{c}_{1}, \mathrm{c}_{2}\right)$ for 30 and $120 \mathrm{~min}\left(\mathrm{t}_{1}, \mathrm{t}_{2}\right)$, and stored for up to 15 days at a temperature of $12 \pm 1{ }^{\circ} \mathrm{C}$. The following parameters were evaluated: titratable acidity, total soluble solids, total phenolic and flavonoid contents, lycopene, total carotenoids, vitamin $\mathrm{C}$, total antioxidant activity, colour $\mathrm{L}^{*} \mathrm{a}^{*} \mathrm{~b}^{*}$ and firmness. Ozonated fruit had higher levels of total soluble solids and higher levels of titratable acidity during and after storage. Exposure of tomatoes to a cooling atmosphere, applying recommended ozonisation process parameters, efficiently inactivated microorganisms that are present on the surface and reduced fruit weight loss, while retaining their firmness and stable colour.
\end{abstract}

Keywords: ozone; vegetables; lycopene; physicochemical parameters

\section{Introduction}

Quality degradation during storage is one of the greatest issues affecting postharvest fruits and vegetables. Tomato (Lycopersicon esculentum) is one of the most important components of the human diet worldwide and is consumed in nature, cooked and processed [1]. This fruit possesses both nutritional and functional properties due to its antioxidant content, including molecules such as ascorbic acid, carotenoids, phenolic acids and flavonoids [2,3]. Tomatoes in the diet increase protection, inter alia, against tumours and cardiovascular diseases $[4,5]$. High polyphenolic and lycopene content in the daily diet reduces the risk of numerous civilisation diseases, as these compounds have potent antioxidant [6] and anti-inflammatory activity [7], and are able to chelate metals and hamper lipid peroxidation [8]. There are many studies indicating a correlation between the consumption of tomatoes and processed tomato products, and a lower risk of developing cancer. Among others, Giovannucci et al. [9] and Paur et al. [10] reported that the consumption of tomatoes and ingestion of the lycopene contained therein positively correlates with a reduction in prostate cancer risk. Others have shown that consumption of tomatoes positively correlated with the content of lycopene in the plasma of study participants, as well as a lower risk of various forms of cancer $[11,12]$. Tomato consumption also influences hormone balance and the body's immune defences [13]. Extensive evidence suggests that lycopene participates in the formation of an antioxidant barrier in the human body which eliminates free radicals, the most impactful cause of cellular ageing, prevents oxidation of low-density lipoprotein (LDL) cholesterol and counteracts atherosclerosis [14,15].

Tomatoes placed at room temperature ripen fast, undergoing changes in colour, firmness, taste and chemical composition, following which they begin to exhibit weight loss [16]. These factors considerably shorten their shelf life and the length of time the fruit retains acceptable quality [17]. To avoid this, tomatoes are most commonly stored at refrigerated 
temperatures, however this is associated with high energy cost. In addition, tomatoes are delicate fruits and are susceptible to numerous fungi diseases, further emphasising the need for more innovative storage solutions. One such potential solution may be technology making use of gaseous ozone treatment for fruit preservation.

Numerous studies, including those of Sachadyn-Król et al. [18], Marchica et al. [19] and Matłok et al. [20], show that the exposure of tomatoes to ozone results in disinfection of the fruit surface and activation of enzymes that delay rotting. Ozone is a powerful antimicrobial substance due to its potential oxidising capacity. Furthermore, the application of ozone in the food industry to extend shelf life and as a bactericidal factor may reduce the use of traditional chemical compounds that are known to be harmful to the natural environment, such as chloride [21,22].

The objective of this study was to develop an innovative method of extending the shelf life of tomatoes with the use of gaseous ozone. Based on these findings, it was possible to determine optimal parameters of the ozonisation process of tomatoes by controlling factors such as the concentration of gaseous ozone in the atmosphere of a refrigerator and an optimal time of tomato exposure to ozone.

\section{Materials and Methods}

\subsection{Plant Material}

The research material were tomatoes of the Rapanui cultivar which belong to an early cultivar of raspberry tomatoes which exhibit continuous growth. The tomatoes came from conventional cultivation sources in the central regions of Poland and were harvested at the full ripening phase (completely red). The tomatoes were properly sorted to remove rotten or damaged fruits, and to ensure unified sizes and weights (each tomato weighed approximately $170 \mathrm{~g}$ ). Tomatoes were transported at $8 \pm 1{ }^{\circ} \mathrm{C}$ for $1 \mathrm{~h}$.

\subsection{Treatmens}

After transportation tomatoes were divided into 5 groups, $5 \mathrm{~kg}$ per group. The first group represented the control sample $\left(\mathrm{c}_{0} \mathrm{t}_{0}\right)$, and the remaining groups were placed in a cooling chamber to which ozone gas was supplied by means of a Korona 02/10 ozone generator (Ekotech, Poland). The air was enriched with ozone gas generated with a capacity of $13 \mathrm{~g} / \mathrm{h}$. The level of ozone generated was measured by means of electrochemical sensors using a GDX-70 measuring head purchased from Alter S.A. (Madrid, Spain) with a measuring range of 0 to $5 \mathrm{mg} \mathrm{L}^{-1}$. The electrochemical ozone sensors operate on the basis of changes in electrolytes as a result of varying concentrations of ozone. During these changes, electrons pass from the one phase to another and the gas atoms which are directly involved in the process undergo changes in oxidation potential. Samples were exposed to the activity of gaseous ozone at concentrations of $0.9\left(c_{1}\right)$ and $2.5\left(c_{2}\right) \mathrm{mg} \mathrm{L}^{-1}$, for $30\left(\mathrm{t}_{1}\right)$ and $120\left(t_{2}\right)$ minutes. Chambers were maintained at $13{ }^{\circ} \mathrm{C}, 95 \%$ relative humidity $(\mathrm{RH})$, with both temperature and $\mathrm{RH}$ monitored and logged during all experiments. The cooling chamber had dimensions of $73 \times 78 \times 211 \mathrm{~cm}$ and was hermetically sealed.

After ozonisation, each group of tomatoes was divided into four parts. The first group was subjected directly to microbiological and chemical analysis and marked as D0. Measurements included determination of the content of total soluble solids, titratable acidity, total content of phenolic compounds, flavonoids, lycopene, total carotenoids and vitamin $C$ levels. Tomato fruit weight loss was determined by means of a weighing balance. Microbiological analysis was conducted to quantify the presence of yeasts and moulds. The remaining ozonised tomatoes, together with the control, were kept under refrigerated conditions at a temperature of $12 \pm 1{ }^{\circ} \mathrm{C}$. Analyses were carried out on days $0,5,10$ and 15 of storage.

\subsection{Titratable Acidity (TA) and Total Soluble Solids (TSS)}

Titratable acidity (TA) and total soluble solids (TSS) were identified by analysis of tomato biomass that had been homogenised to pulp using a portable Bosch ErgoMixx food 
processor MSM66120 (Gerlingen, Germany). Titratable acidity was determined according to Aguayo et al. [23]. Briefly, $10 \mathrm{~g}$ of homogenised pulp were diluted in $50 \mathrm{~mL}$ of distilled water and titrated with standardised $0.1 \mathrm{~N} \mathrm{NaOH}$ up to $\mathrm{pH}$ 8.1. The volume of $\mathrm{NaOH}$ added was converted to a percent citric acid [(volume of $\mathrm{NaOH} \times 0.1 \mathrm{~N} \times 0.064 / 10.00 \mathrm{~g}$ of juice) $\times 100$ ] and expressed in terms of fresh weight. TSS content in the liquid obtained from the homogenised pulp was determined using a manual digital Atago Brix (0-32\%) refractometer (Minato-ku, Japan) and expressed as a percentage weight/volume [23]. These results were calculated as the arithmetic mean of 3 measurements.

\subsection{Total Phenolic Content (TPC)}

To analyse the total phenolic content (TPC), a Folin-Ciocalteu method was used [24]. In brief, $20 \mathrm{~g}$ of sample were subjected to extraction using $100 \mathrm{~mL}$ of ethanol for $24 \mathrm{~h}$. Following this, $0.5 \mathrm{~mL}$ of distilled water was added to $0.125 \mathrm{~mL}$ diluted extract, followed by $0.125 \mathrm{~mL}$ of Folin-Ciocalteu reagent. After $3 \mathrm{~min}, 1.250 \mathrm{~mL}$ of sodium carbonate was added $(7.5 \%)$, and the volume was made up to $3.0 \mathrm{~mL}$ with water. The solution was kept for $30 \mathrm{~min}$ at $40^{\circ} \mathrm{C}$ in a WNB 7 Memmert water bath (Schwabach, Germany). The absorbance was measured spectrophotometrically at $760 \mathrm{~nm}$ using a Tecan Spark ${ }^{\mathrm{TM}} 10 \mathrm{M}$ spectrophotometer (Männedorf, Switzerland). TPC was expressed as mg Gallic acid equivalents (GAE) per $\mathrm{Kg}$ fresh weight based on a calibration curve prepared with Gallic acid. All analyses were performed in triplicate.

\subsection{Total Flavonoid Content (TFC)}

The total flavonoid content (TFC) was determined using spectrometric methods with the application of aluminium chlorohydrate [24]. Briefly, $8 \mathrm{~mL}$ of ethanol was added to $1 \mathrm{~mL}$ sample, followed by addition of $0.2 \mathrm{~mL}$ of $5 \% \mathrm{NaNO}_{2}$ aqueous solution. After $5 \mathrm{~min}$, $0.2 \mathrm{~mL}$ of $10 \%$ aluminium chlorohydrate aqueous solution was applied. After a further $6 \mathrm{~min}, 0.6 \mathrm{~mL}$ of $4 \% \mathrm{NaOH}$ aqueous solution was added. Finally, distilled water was added to a volume of $10 \mathrm{~mL}$. Simultaneously, a blind sample without extract was prepared. Absorbance measurement was performed at a wavelength of $430 \mathrm{~nm}$. TFC values were read out from the sample curve, and expressed as mg of rutin equivalent (RE) per $\mathrm{kg}$ fresh weight ( $\mathrm{mg} \mathrm{kg}^{-1}$ rutin equivalent RE). All experiments were performed in triplicate.

\subsection{Total Carotenoids and Lycopene Content}

Total carotenoid and lycopene extraction and determination were conducted as described by Lee [25] and Fish et al. [26], respectively. In this method, a mixture containing acetone and $0.05 \%$ of butylated hydroxytoluene (BHT) was added to the tomato pulp ( $5 \mathrm{~mL}$ to $0.5 \mathrm{~g}$ pulp), after which $5 \mathrm{~mL}$ ethanol and $10 \mathrm{~mL}$ hexane were added to the mixture. The mixture was shaken for $30 \mathrm{~min}$ on ice and then $3 \mathrm{~mL}$ of distilled water was added and the mixture was shaken for another $5 \mathrm{~min}$. During the extraction process, the samples were protected from light by wrapping in aluminium foil to avoid photooxidation of lycopene. After the shaking stage, samples were left without shaking for $5 \mathrm{~min}$ in order to separate the phases. The total carotenoid and lycopene content was determined by means in a Tecan Spark $^{\mathrm{TM}} 10 \mathrm{M}$ spectrophotometer (Männedorf, Switzerland) at wavelengths of 450 and $503 \mathrm{~nm}$, respectively. Absorbance measurement was carried out in the hexane layer.

The total carotenoids quantity was expressed as $\mathrm{mg} \beta$-carotene equivalents per $\mathrm{kg}$ of fresh weight ( $\left.\mathrm{mg} \mathrm{kg}^{-1} \beta-\mathrm{CaE}\right)$. Lycopene molar extinction $\mathrm{e}=17.2 \times 10^{4} \mathrm{M}^{-1} \mathrm{~cm}^{-1}$ in $\mathrm{n}$-hexane was used for lycopene content determination and the results were expressed as $\mathrm{mg} \mathrm{kg}{ }^{-1}$. All experiments were performed in triplicate.

\subsection{Vitamin C Content Analysis}

The vitamin C content was analysed by titration with 2,6-dichlorophenolindophenol (DCIP). A detailed description of the vitamin C content analysis is described in Onopiuk et al. [27]. The ascorbic acid content was expressed as $\mathrm{mg}$ per $\mathrm{kg}$ of fresh tomatoes. All experiments were performed in triplicate. 


\subsection{Total Antioxidant Activity (TAA)}

The 1,1-diphenyl-2-picrylhydrazyl (DPPH) free radical scavenging activity of the tomatoes was determined according to a modified method previously described by Lu et al. [28]. Tomato fruit extract $(0.4 \mathrm{~mL})$ was mixed with $3.6 \mathrm{~mL}$ of DPPH solution $\left(0.024 \mathrm{~g} \mathrm{~mL}^{-1}\right)$ and incubated for $30 \mathrm{~min}$ in darkness. The absorbance was measured at a wavelength of $515 \mathrm{~nm}$. Ethanol was used as a blank and three replications were made for all measurements. The total antioxidant activity (TAA) was expressed as \% reduction of DPPH according to the following equation:

$$
\operatorname{TAA}(\%)=\left(1-\mathrm{A}_{\mathrm{s}} / \mathrm{A}_{\mathrm{c}}\right) \times 100 \%
$$

where $A_{s}$ is the absorbance of the sample and $A_{c}$ is the absorbance of the control (prepared according to identical procedures, but without the tomato extract).

\subsection{Colour Measurements}

The instrumental measurement of the colour parameters of tomatoes was done according to the $\mathrm{L}^{*} \mathrm{a}^{*} \mathrm{~b}^{*}$ system using a Konica Minolta chromameter CR-400 (Tokyo, Japan). The chromameter was calibrated on the CIE LAB colour space system using a white plate $\left(L^{*}=98.45, a^{*}=-0.10, b^{*}=-0.13\right)$. The readout for the sample was calculated as the arithmetic mean of 10 measurements as described by Mauro et al. [29].

\subsection{Firmness}

Fruit firmness was determined as described by Aragüez et al. [30] using an Instron 5965 Universal Testing Machine (Norwood, MA, USA). Firmness was measured via compression using a $50 \mathrm{~N}$ load cell. After establishing zero-force contact between the probe and the horizontally positioned fruit, specimens were compressed $2.5 \mathrm{~mm}$ at the equatorial region of each fruit. Firmness was expressed as the maximum force in Newtons $(\mathrm{N})$ needed to penetrate a tomato and was calculated as the arithmetic mean of 6 measurements.

\subsection{Evaluation of Fruit Weight Losses during the Storage Time}

Both ozonised tomatoes and the control group were subjected to weight control. Also the percentage decrease of weight was determined for ozonised and non-ozonised fruit. Fruits were stored at $12 \pm 1{ }^{\circ} \mathrm{C}$ for 15 days after ozonisation.

\subsection{Microbial Analysis (Yeasts and Moulds)}

Determination of the presence of yeasts and moulds was carried out according to standard PN-ISO 7954:1999. Details of the microbiological analysis method used have already been described by Onopiuk et al. [31]. Results were provided in colony-forming units and were expressed as $\log _{10} \mathrm{CFU} \mathrm{g} \mathrm{g}^{-1}$.

\subsection{Statistical Analysis}

Experimental data were subjected to analysis of variance (ANOVA) using Statistica 12.5 software in order to determine the impact of ozonisation and storage time on response parameters (two-factor experiment using ozone dosage, treatment duration and storage period). The differences between groups were tested according to Tukey's test (significance level of $p \leq 0.05)$.

\section{Results and Discussion}

\subsection{Titratable Acidity (TA) and Total Soluble Solids (TSS)}

The main reasons for minimising the storage time of fresh tomatoes are biochemical reactions which take place in tissues, and the growth of microorganisms on the fruit surface. Fermentation is one of the biochemical processes in which sugars are metabolised, resulting in an increase of the titratable acidity changes. Titratable acidity (TA) is a fundamental parameter which affects fruit and vegetable quality, and increases in acidity may be indicative of incorrect storage conditions [27]. TSS is a refractometric index that indicates 
the proportion of dissolved solids in a solution. It reflects the sum of sugars (sucrose and hexoses, 65\%), acids (citrate and malate, 13\%) and other minor components (phenols, amino acids, soluble pectins, ascorbic acid and minerals) in the tomato fruit pulp [16,32] Sugars combined with organic acids have a decisive impact on the tomato fruit taste, as well as its utility in the processing industry [33]. Higher content of sugars and TA are associated with better taste values in tomatoes. TSS and titratable acidity data for ozonised and control tomatoes after $0,5,10$ and 15 days of storage are presented in Table 1.

Table 1. Impact of concentration and ozonisation time on the total soluble solids and titratable acidity measured after 0,5 , 10 and 15 days of storage at $12 \pm 1^{\circ} \mathrm{C}$.

\begin{tabular}{|c|c|c|c|c|c|c|}
\hline \multirow{2}{*}{$\begin{array}{c}\text { Chemical Quality } \\
\text { Parameters }\end{array}$} & \multirow{2}{*}{\multicolumn{2}{|c|}{$\begin{array}{l}\text { Concentration and } \\
\text { Ozonisation Time }\end{array}$}} & \multicolumn{4}{|c|}{ Storage Period (Days) } \\
\hline & & & D0 & D5 & D10 & D15 \\
\hline \multirow[t]{5}{*}{ Total soluble solids (\%) } & \multicolumn{2}{|c|}{ control } & $4.10^{\mathrm{A}} \pm 0.10$ & $4.27^{\mathrm{Aa}} \pm 0.15$ & $4.83^{\mathrm{Ba}} \pm 0.12$ & $4.40^{\mathrm{Aa}} \pm 0.10$ \\
\hline & \multirow{2}{*}{$0.9 \mathrm{mg} \mathrm{L}^{-1}$} & $30 \mathrm{~min}$ & $4.23^{\mathrm{A}} \pm 0.06$ & $4.50^{\mathrm{ABab}} \pm 0.10$ & $5.10^{\mathrm{Cb}} \pm 0.10$ & $4.81^{\mathrm{BCb}} \pm 0.17$ \\
\hline & & $120 \mathrm{~min}$ & $4.07^{\mathrm{A}} \pm 0.15$ & $4.57^{\mathrm{Bab}} \pm 0.15$ & $5.27^{\mathrm{Cb}} \pm 0.06$ & $4.80^{\mathrm{Bb}} \pm 0.10$ \\
\hline & \multirow{2}{*}{$2.5 \mathrm{mg} \mathrm{L}^{-1}$} & $30 \mathrm{~min}$ & $4.13^{\mathrm{A}} \pm 0.06$ & $4.77^{\mathrm{Bbc}} \pm 0.12$ & $5.33^{\mathrm{Cbc}} \pm 0.12$ & $5.03^{\mathrm{BCb}} \pm 0.15$ \\
\hline & & $120 \mathrm{~min}$ & $4.27^{\mathrm{A}} \pm 0.15$ & $4.93^{\mathrm{Bc}} \pm 0.06$ & $5.57^{\mathrm{Cc}} \pm 0.06$ & $5.10^{\mathrm{Bb}} \pm 0.10$ \\
\hline \multirow[t]{5}{*}{ Titratable acidity (\%) } & \multicolumn{2}{|c|}{ control } & $0.40^{\mathrm{C}} \pm 0.02$ & $0.37^{\mathrm{BCb}} \pm 0.04$ & $0.31^{\mathrm{Bc}} \pm 0.01$ & $0.25^{\mathrm{Ab}} \pm 0.02$ \\
\hline & \multirow{2}{*}{$0.9 \mathrm{mg} \mathrm{L}^{-1}$} & $30 \mathrm{~min}$ & $0.41^{\mathrm{C}} \pm 0.02$ & $0.34^{\mathrm{Bab}} \pm 0.02$ & $0.29^{\mathrm{ABbc}} \pm 0.02$ & $0.26^{\mathrm{Ab}} \pm 0.02$ \\
\hline & & $120 \mathrm{~min}$ & $0.41^{\mathrm{C}} \pm 0.03$ & $0.32^{\mathrm{Bab}} \pm 0.01$ & $0.28^{\mathrm{ABbc}} \pm 0.03$ & $0.23^{\mathrm{Ab}} \pm 0.02$ \\
\hline & \multirow{2}{*}{$2.5 \mathrm{mg} \mathrm{L}^{-1}$} & $30 \mathrm{~min}$ & $0.43^{\mathrm{C}} \pm 0.01$ & $0.29^{\mathrm{Ba}} \pm 0.03$ & $0.24^{\mathrm{ABab}} \pm 0.02$ & $0.21^{\mathrm{Aab}} \pm 0.02$ \\
\hline & & $120 \mathrm{~min}$ & $0.43^{C} \pm 0.01$ & $0.29^{\mathrm{Bab}} \pm 0.04$ & $0.21^{\mathrm{Aa}} \pm 0.01$ & $0.17^{\mathrm{Aa}} \pm 0.02$ \\
\hline
\end{tabular}

A-C-capital letters show significant differences for each treatment during storage time, a-c-lowercase letters show significant differences between treatments within each storage time. The values represented the mean \pm standard error.

During the 15-day storage period, an increase in TSS content was reported both in the control as well as in each of the ozonised groups of tomatoes, which results from biological processes which take place in fruit and vegetables. The content of TSS appeared to increase up to day 10 of storage, but reduced content was observed at day 15 of storage. During storage (D5, D10, D15), ozonised tomatoes had a higher content of TSS in comparison to the control, which, according to Javanmardi and Kubot [17], may result from distinct changes in the proportion of glucose to fructose and levels of organic acids during storage. Additionally, as a result of transpiration, water loss takes place during storage, causing tomatoes to lose both firmness and weight, while also causing TSS to increase. These findings are in agreement with those reported by Inestroza-Lizardo et al. [34] and Liu et al. [35], varying by only by $4.07-4.81 \%$. The lowest content of TSS during storage was observed in tomatoes from the control group, while the highest content was observed in tomatoes from the groups that were ozonised with a dose of $2.5 \mathrm{mg} \mathrm{L}^{-1}$ for 30 and $120 \mathrm{~min}\left(\mathrm{c}_{2} \mathrm{t}_{1}\right.$ and $\left.\mathrm{c}_{2} \mathrm{t}_{2}\right)$. Ozonisation and 15-day storage of tomatoes caused statistically significant $(p \leq 0.05)$ changes in TSS.

The TA in the tomato fruit was $0.40 \%$ of citric acid at the beginning of the experiment (D0). Similar TA values were reported by Odriozola-Serrano et al. [36], who observed acidity of tomatoes ranging from $0.34 \%$ to $0.59 \%$. The value of the TA of tomatoes of all groups at D0 did not differ statistically significantly $(p \leq 0.05)$. During storage, a noticeable decrease in acidity was observed across all groups and after 15 days, the acidity dropped to $0.17-0.25 \%$. Acidity of tomatoes depends on their maturity degree, with more mature fruit exhibiting lower acidity. The greatest difference in TA, approximately $60 \%$ reduction, was observed in the tomatoes which were ozonised with $2.5 \mathrm{mg} \mathrm{L}^{-1}$ for $120 \mathrm{~min}\left(\mathrm{c}_{2} \mathrm{t}_{2}\right)$, after 15 days of storage. The decrease in TA during storage is a natural phenomenon, which has also been demonstrated by Zou et al. [37] and Buendía-Moreno et al. [38]. According to Tigist et al. [39], the decrease in TA during the storage time could be related to a higher respiration rate as ripening advances, as organic acids are used as a substrate in the respiration process. 


\subsection{Total Phenolic, Total Flavonoid, Lycopene, Carotenoids and Vitamin C Content Determination}

Tomatoes constitute a rich source of many substances with antioxidant properties, including polyphenols, flavonoids and carotenoids (particularly lycopene and $\beta$-carotene), and are also a valuable source of vitamin $\mathrm{C}$. The impact of ozonisation on the total phenolic content (TPC), total flavonoids content (TFC), total lycopene, total carotenoids and vitamin C content are presented in Table 2.

Table 2. Effect of ozone concentration, time of ozonation and storage on the total phenolic content, flavonoids, lycopene, total carotenoids and vitamin $\mathrm{C}$ of Rapanui tomatoes stored at $12 \pm 1{ }^{\circ} \mathrm{C}$.

\begin{tabular}{|c|c|c|c|c|c|c|}
\hline \multirow{2}{*}{$\begin{array}{c}\text { Chemical Quality } \\
\text { Parameters }\end{array}$} & \multirow{2}{*}{\multicolumn{2}{|c|}{$\begin{array}{l}\text { Concentration and } \\
\text { Ozonisation Time }\end{array}$}} & \multicolumn{4}{|c|}{ Storage Period (Days) } \\
\hline & & & Do & D5 & D10 & D15 \\
\hline \multirow{5}{*}{$\begin{array}{l}\text { Total phenolic content } \\
\text { (TPC) } \mathrm{mg} \mathrm{kg}^{-1} \mathrm{GAE}\end{array}$} & \multicolumn{2}{|c|}{ control } & $296.9^{\mathrm{A}} \pm 6.9$ & $331.4^{\mathrm{Ba}} \pm 6.4$ & $321.4^{\mathrm{Ba}} \pm 10.8$ & $288.9^{\mathrm{Aa}} \pm 8.1$ \\
\hline & \multirow{2}{*}{$0.9 \mathrm{mg} \mathrm{L}^{-1}$} & $30 \mathrm{~min}$ & $287.5^{\mathrm{A}} \pm 11.6$ & $349.2^{\mathrm{Cab}} \pm 11.7$ & $331.0^{\mathrm{BCa}} \pm 6.7$ & $306.7^{\mathrm{ABab}} \pm 5.9$ \\
\hline & & $120 \mathrm{~min}$ & $289.3^{\mathrm{A}} \pm 11.3$ & $357.7^{\mathrm{Cb}} \pm 7.9$ & $354.0^{\mathrm{Cb}} \pm 6.7$ & $325.2^{\mathrm{Bb}} \pm 3.7$ \\
\hline & \multirow{2}{*}{$2.5 \mathrm{mg} \mathrm{L}^{-1}$} & $30 \min$ & $276.9^{\mathrm{A}} \pm 12.1$ & $334.1^{\mathrm{Bab}} \pm 12.8$ & $328.7^{\mathrm{Ba}} \pm 2.3$ & $299.4^{\mathrm{Aa}} \pm 11.9$ \\
\hline & & $120 \mathrm{~min}$ & $279.2^{\mathrm{A}} \pm 14.1$ & $334.6^{\mathrm{Cab}} \pm 8.1$ & $329.7^{\mathrm{BCa}} \pm 9.9$ & $304.5^{\mathrm{ABab}} \pm 8.0$ \\
\hline \multirow{6}{*}{$\begin{array}{l}\text { Total flavonoid content } \\
\text { (TFC) } \mathrm{mg} \mathrm{kg}^{-1} \mathrm{RE}\end{array}$} & \multicolumn{2}{|c|}{ control } & $170.4^{\mathrm{B}} \pm 8.2$ & $151.6^{\mathrm{Ba}} \pm 8.1$ & $121.9^{\mathrm{Aa}} \pm 8.0$ & $101.2^{\mathrm{Aa}} \pm 8.2$ \\
\hline & $09 \mathrm{mo} \mathrm{I}$ & $30 \mathrm{~min}$ & $167.6^{C} \pm 3.8$ & $160.3^{\mathrm{BCab}} \pm 5.5$ & $148.4^{\mathrm{Bb}} \pm 8.4$ & $120.8^{\mathrm{Aab}} \pm 7.3$ \\
\hline & $0.9 \mathrm{~m}$ & $120 \mathrm{~min}$ & $174.2^{\mathrm{C}} \pm 6.6$ & $171.1^{\mathrm{Cb}} \pm 4.3$ & $151.2^{\mathrm{Bb}} \pm 6.2$ & $134.6^{\mathrm{Ab}} \pm 6.5$ \\
\hline & 2 & $30 \mathrm{~min}$ & $179.5^{\mathrm{B}} \pm 8.9$ & $166.3^{\mathrm{Bab}} \pm 6.8$ & $142.7^{\mathrm{Ab}} \pm 7.4$ & $127.0^{\mathrm{Ab}} \pm 8.4$ \\
\hline & & $120 \mathrm{~min}$ & $170.6^{\mathrm{B}} \pm 7.7$ & $159.0^{\mathrm{Bab}} \pm 4.2$ & $137.9^{\mathrm{Aab}} \pm 6.2$ & $122.9^{\mathrm{Ab}} \pm 8.9$ \\
\hline & \multicolumn{2}{|c|}{ control } & $159.7^{\mathrm{Bb}} \pm 4.2$ & $173.0^{\mathrm{Ca}} \pm 3.6$ & $152.3^{\mathrm{Bb}} \pm 3.8$ & $129.3^{\mathrm{Aa}} \pm 3.2$ \\
\hline \multirow{4}{*}{ Lycopene (mg kg-1) } & \multirow{2}{*}{$0.9 \mathrm{mg} \mathrm{L}^{-1}$} & $30 \mathrm{~min}$ & $143.7^{\mathrm{Aa}} \pm 3.2$ & $190.0^{\mathrm{Cbc}} \pm 3.0$ & $165.3^{\mathrm{Bc}} \pm 3.5$ & $143.0^{\mathrm{Ab}} \pm 5.2$ \\
\hline & & $120 \mathrm{~min}$ & $153.3^{\mathrm{Ab}} \pm 3.1$ & $193.7^{\mathrm{Cc}} \pm 4.0$ & $175.0^{\mathrm{Bc}} \pm 5.2$ & $158.3^{\mathrm{Ac}} \pm 4.5$ \\
\hline & \multirow{2}{*}{$2.5 \mathrm{mg} \mathrm{L}^{-1}$} & $30 \mathrm{~min}$ & $157.8^{\mathrm{Bb}} \pm 4.8$ & $181.3^{\mathrm{Cab}} \pm 4.2$ & $138.0^{\mathrm{Aa}} \pm 6.6$ & $128.3^{\mathrm{Aa}} \pm 3.5$ \\
\hline & & $120 \mathrm{~min}$ & $150.5^{\mathrm{Cab}} \pm 3.5$ & $173.0^{\mathrm{Da}} \pm 2.6$ & $141.0^{\mathrm{Bab}} \pm 3.5$ & $125.7^{\mathrm{Aa}} \pm 3.8$ \\
\hline \multirow{5}{*}{$\begin{array}{c}\text { Total carotenoids } \\
\text { content }\left(\mathrm{mg} \mathrm{kg}^{-1}\right. \\
\beta-\mathrm{CaE})\end{array}$} & \multicolumn{2}{|c|}{ control } & $231.7^{\mathrm{Bab}} \pm 2.5$ & $258.7^{\mathrm{Da}} \pm 4.5$ & $243.0^{\mathrm{Cab}} \pm 3.6$ & $206.7^{\text {Acd }} \pm 3.1$ \\
\hline & \multirow{2}{*}{$0.9 \mathrm{mg} \mathrm{L}^{-1}$} & $30 \mathrm{~min}$ & $238.7^{\mathrm{Bbc}} \pm 3.5$ & $270.7^{\mathrm{Db}} \pm 3.8$ & $249.3^{\mathrm{Cb}} \pm 5.1$ & $212.3^{\mathrm{Ad}} \pm 3.1$ \\
\hline & & $120 \mathrm{~min}$ & $243.3^{B c} \pm 3.8$ & $283.3^{\mathrm{C}} \pm 4.0$ & $275.7^{\mathrm{Cc}} \pm 2.9$ & $193.3^{\mathrm{Aab}} \pm 5.1$ \\
\hline & \multirow{2}{*}{$2.5 \mathrm{mg} \mathrm{L}^{-1}$} & $30 \mathrm{~min}$ & $232.3^{\mathrm{Bab}} \pm 4.0$ & $269.0^{\mathrm{Db}} \pm 2.6$ & $250.0^{\mathrm{Cb}} \pm 4.4$ & $199.3^{\mathrm{Abc}} \pm 4.5$ \\
\hline & & $120 \mathrm{~min}$ & $228.7^{\mathrm{Ba}} \pm 3.5$ & $256.7^{\mathrm{Ca}} \pm 3.8$ & $234.3^{\mathrm{Ba}} \pm 3.8$ & $188.0^{\mathrm{Aa}} \pm 4.6$ \\
\hline \multirow{5}{*}{ Vitamin $C\left(\mathrm{mg} \mathrm{kg}^{-1}\right)$} & \multicolumn{2}{|c|}{ control } & $210.8^{\mathrm{A}} \pm 3.2$ & $229.2^{\mathrm{B}} \pm 3.2$ & $210.8^{\mathrm{A}} \pm 6.4$ & $201.7^{\mathrm{A}} \pm 8.4$ \\
\hline & \multirow{2}{*}{$0.9 \mathrm{mg} \mathrm{L}^{-1}$} & $30 \mathrm{~min}$ & $216.3^{B} \pm 6.4$ & $234.7^{C} \pm 8.4$ & $203.5^{\mathrm{AB}} \pm 5.5$ & $190.7^{\mathrm{A}} \pm 6.4$ \\
\hline & & $120 \mathrm{~min}$ & $207.2^{\mathrm{AB}} \pm 3.2$ & $225.5^{\mathrm{B}} \pm 9.5$ & $205.3^{\mathrm{A}} \pm 6.4$ & $192,5^{\mathrm{A}} \pm 9.5$ \\
\hline & \multirow{2}{*}{$2.5 \mathrm{mg} \mathrm{L}^{-1}$} & $30 \mathrm{~min}$ & $214.5^{\mathrm{BC}} \pm 5.5$ & $232.8^{C} \pm 3.2$ & $205.3^{\mathrm{AB}} \pm 11.4$ & $188.8^{\mathrm{A}} \pm 8.4$ \\
\hline & & $120 \mathrm{~min}$ & $205.3^{\mathrm{B}} \pm 3.2$ & $229.2^{\mathrm{C}} \pm 8.4$ & $198.0^{\mathrm{AB}} \pm 5.5$ & $185.2^{\mathrm{A}} \pm 8.4$ \\
\hline
\end{tabular}

A-D—capital letters show significant differences for each treatment during storage time, a-d-lowercase letters show significant differences between treatments within each storage time. The values represented the mean \pm standard error.

At D0, the TPC in the control group and ozonised groups were comparable and within 276.9-296.9 mg kg${ }^{-1}$ GAE. A similar TPC of $258.75 \pm 18.04 \mathrm{mg} \mathrm{kg}^{-1}$ GAE was also reported by Bravo et al. in control tomatoes [40]. Del Giudice et al. [41] reported that the TPC in a control group was equal to $169.7-268.9 \mathrm{mg} \mathrm{kg}^{-1}$ GAE. Choi et al. [4] reported that the TPC greatly depends on the tomato cultivar, and Ding et al. [42] asserted that the crop location influences the TPC. The greatest difference in TPC with respect to the control, a difference of $32.6 \mathrm{mg} \mathrm{kg}^{-1} \mathrm{GAE}$, was observed in $\mathrm{c}_{1} \mathrm{t}_{2}$ tomatoes at D10. No statistically significant differences were observed in the other groups $(p \leq 0.05)$. Glowacz and Rees [43] also described the lack of a clear effect of ozone on TPC in sweet pepper fruit and Tzortzakis et al. [44] reported similarly inconclusive findings in tomato fruit cv. Carousel.

The antioxidant properties of flavonoids result from the presence of conjugated, double binding and hydroxyl groups, by means of which they may inhibit free radicals and chelate metals with a pro-oxidation nature [45]. The presence of flavonoids in tomatoes enhances antioxidant properties of the other nutritional components. The flavonoid con-tent of Rapanui tomatoes analysed at the beginning of the experiment (D0) was in the range of 
167.6-179.5 $\mathrm{mg} \mathrm{kg}^{-1} \mathrm{RE}$. During storage, flavonoids became partially degraded as a result of natural biochemical reactions taking place in tissues [6]. The greatest decrease in TFC during 15 days of storage was observed in the control group, where levels dropped to $101.2 \mathrm{mg} \mathrm{kg}^{-1}$ rutin equivalent (40.6\% in comparison to levels determined at D0). The greatest stability in flavonoid content was observed in tomatoes ozonised with a dose of $0.9 \mathrm{mg} \mathrm{L}^{-1}$ for $120 \mathrm{~min}$, where a decrease of only $22.73 \%$ was detected. The $0.9 \mathrm{mg} \mathrm{L}^{-1}$ dose appeared to be more effective in inhibiting flavonoid degradation than the higher dose of $2.5 \mathrm{mg} \mathrm{L}^{-1}$. After exposure of tomatoes from groups $\mathrm{c}_{2} \mathrm{t}_{1}$ and $\mathrm{c}_{2} \mathrm{t}_{2}$ to ozone, a spontaneous decomposition of the ozone can take place, which would lead to formation of free radicals such as hydroperoxyl $(\mathrm{H} 2 \mathrm{O} \bullet)$, hydroxyl $(\bullet \mathrm{OH})$ and superoxide $\left(\bullet \mathrm{O}_{2}{ }^{-}\right)$. High levels of ozone may cause damage to epidermis and/or epidermal tissues of the fruit [46]. Although the level and composition of flavonoids in tomato fruit depends considerably on the cultivar, environmental conditions and storage conditions, the TFC levels recorded in this study are in agreement with the results obtained by Ilahy et al. [24]. They tested 4 different tomato cultivars and found that the flavonoid content of mature fruit was $133-474 \mathrm{mg} \mathrm{kg}^{-1}$ RE. A similar TFC content in tomatoes was recorded in the studies performed by Klunklin et al. [47].

During fruit growth, the green pigment chlorophyll is degraded, and carotenoids are synthesised. Carotenoids, particularly lycopene and $\beta$-carotene, are components of tomatoes and are responsible for the characteristic red and orange colour of mature tomatoes. Carotenoids have a great impact on consumer perception of fresh tomatoes [35]. According to the literature, ripe tomatoes contain $97-254 \mathrm{mg} \mathrm{kg}^{-1}$ of lycopene, while the total content of carotenoids is in the range of $105-278 \mathrm{mg} \mathrm{kg}^{-1} \beta-\mathrm{CaE}$ [28]. The carotenoid content also depends on the cultivar, environmental conditions and storage conditions. An environmental factor that determines the level of carotenoids, including lycopene, is the storage temperature. According to Park et al. [48] an optimal storage temperature for maintenance of high lycopene and $\beta$-carotene levels is $12^{\circ} \mathrm{C}$.

Rapanui tomatoes placed in an atmosphere with ozone at concentrations of 0.9 or $2.5 \mathrm{mg} \mathrm{L}^{-1}$ for of 30 or $120 \mathrm{~min}$ and then stored at a temperature of $12{ }^{\circ} \mathrm{C}$ contained $143.7-157.8 \mathrm{mg} \mathrm{kg}^{-1}$ of lycopene and $228.7-243.3 \mathrm{mg} \mathrm{kg}^{-1} \beta-\mathrm{CaE}$ of total carotenoids at D0. At D5, an increase in the total carotenoid content, including lycopene, was recorded. The greatest increase in lycopene was recorded for the $\mathrm{c}_{1} \mathrm{t}_{1}$ group $\left(0.9 \mathrm{mg} \mathrm{L}^{-1}, 30 \mathrm{~min}\right)$, while the smallest increase was recorded in the control group. During further storage (D10 and D15) a statistically significant $(p \leq 0.05)$ decrease in total carotenoids and lycopene was recorded in the majority of groups. Tomatoes from group $\mathrm{c}_{1} \mathrm{t}_{2}\left(0.9 \mathrm{mg} \mathrm{L}^{-1}, 120 \mathrm{~min}\right)$ were an exception, where lycopene content at D15 did not considerably change in comparison to D0 $\left(158.3 \pm 4.5 \mathrm{mg} \mathrm{kg}^{-1}\right)$. Extensive loss of lycopene observed in groups $\mathrm{c}_{2} \mathrm{t}_{1}$ and $\mathrm{C}_{2} \mathrm{t}_{2}$ (a reduction of $18.69 \%$ and $16.48 \%$, respectively) during storage could have resulted from an excessive dose of ozone. According to Kopec et al. [49], under the influence of oxidisers, ozone-induced oxidation of one of double conjugated bonds of lycopene, as well as decomposition and formation of apo-lycopenal or apo-lycopenon with a terminal aldehyde or ketone group may take place. Multi-stage decomposition of lycopene also results in the formation of apo-carotenodiols, which have the aldehyde group at both ends of the molecule. Ölmez and Akbas [50] studied the effects of ozone on salad and concluded that they were highly concentration dependent: ozone may have favourable effects up to a certain level, but after reaching a critical point it accelerates the browning reactions, causing rapid deterioration of the fruit and vegetable quality. Decreases in the total lycopene and carotenoid content during storage is a natural process which takes place in tomatoes, which was demonstrated by (inter alia) Park et al. [48], who monitored the storing of black 'Hei' tomatoes for 20 days at three temperature variations: 8,12 and $20^{\circ} \mathrm{C}$.

Ripe tomatoes constitute a rich source of vitamin $\mathrm{C}$, the content of which in fresh red tomatoes is $158.0 \pm 11 \mathrm{mg} \mathrm{kg}^{-1}$ according to Georgé et al. [51], but its level also depends on the cultivar and the degree of fruit maturity [24]. Pinela et al. [52], studying Batateiro 
tomatoes, reported a vitamin $C$ content of $108.6 \pm 0.9 \mathrm{mg} \mathrm{kg}^{-1}$, while it was almost two-fold more in Coração tomatoes, amounting to $185.6 \pm 0.4 \mathrm{mg} \mathrm{kg}^{-1}$ of fresh weight.

The levels of vitamin $C$ recorded in this study are in the range of $176.0-242.0 \mathrm{mg} \mathrm{kg}^{-1}$, with the average levels recorded at $210.83 \pm 5.76 \mathrm{mg} \mathrm{kg}^{-1}$. After ozonisation, at D0, no statistically significant changes in the vitamin $C$ content between experimental groups were recorded. A slight decrease in vitamin C content at D10 and D15 may have occurred as a result of oxidation of L-ascorbic acid to dehydroascorbic, which was further oxidised with the loss of biological activity. However, no significant correlation between the ozonisation dose and time and the vitamin $C$ stability has been verified and the control group exhibited similar vitamin $C$ content in comparison to the groups which were subjected to ozonisation. This lack of correlation between ozone treatment and vitamin $C$ stability was also reflected in the research of Glowacz and Rees [43], who studied red and green pepper fruit. Ölmez and Akbas [50] equally did not conclude any correlation between the ozone dose (0.5-4.5 $\left.\mathrm{mg} \mathrm{L}^{-1}\right)$ and vitamin $C$ stability during 12-day storage of salad. A satisfactory stability of vitamin $C$ in our experiment was probably obtained because of the use of optimal temperature during storage $\left(12{ }^{\circ} \mathrm{C}\right)$. Vitamin $\mathrm{C}$ belongs to thermolabile compounds, which are very sensitive to a high temperature [53]. Dewanto et al. [54] demonstrated the impact of high temperatures on loss of vitamin $C$ content in tomatoes. Only $2 \mathrm{~min}$ of exposure of tomatoes to high temperature $\left(88^{\circ} \mathrm{C}\right)$ caused vitamin $\mathrm{C}$ loss of 0.76 to $0.68 \mu \mathrm{mol} \mathrm{g}^{-1}$ in comparison to tomatoes not subjected to the thermal treatment.

\subsection{Total Antioxidant Activity (TAA)}

As a measurement of the antioxidant properties of tomatoes, the ability of tomato extract to deactivate free radicals was determined with the use of DPPH. Figure 1 shows that Rapanui tomatoes had an antioxidant activity at an average level of $32.04 \pm 0.90$ (D0), respectively. As was shown by Javanmardi and Kubota [17], only slight differences between the TAA of the various treatment groups were observed during the first 5 days of storage and these were probably as a result of water loss due to respiration and transpiration. During extended storage, an increase in TAA was observed in most of the treatment groups, although in both control and the groups treated with $0.9 \mathrm{mg} \mathrm{L}^{-1}$ of ozone, this increase was lower than in the group treated with $2.5 \mathrm{mg} \mathrm{L}^{-1}$ ozone. Tomatoes from the $\mathrm{c}_{2} \mathrm{t}_{1}$ group were characterised by the highest antioxidant activity at D5 and D10 $(35.29 \pm 1.46 \%$ and $41.76 \pm 1.87 \%$, respectively). The highest TAA at D15 was observed in the $\mathrm{c}_{2} \mathrm{t}_{2}$ group $(53.25 \pm 2.13 \%)$. The increase in antioxidant activity observed in tomatoes from the $c_{2}$ group during storage could be related to the ripening process and the metabolism of phenolic compounds, as was observed by Mirdehghan and Valero [55] and Javanmardi and Kubota [17]. A high correlation was shown between the phenol content and the total antioxidant activity $\left(p<0.001, \mathrm{r}^{2}=0.720\right)$ [55]. Radoni et al. [56] demonstrated that the presence of ozone does not cause any loss of biologically active substances in tomatoes during the storage. Additionally, sufficiently high concentrations of gas may even inhibit enzymes that cause oxidation of phenolic compounds, which increases the total antioxidant activity. An increase in TAA upon ozonation was also reported by Glowacz and Rees [43].

\subsection{Colour Measurements}

The colour of tomatoes evaluated in the $L^{*} a^{*} b^{*}$ system is presented in Table 3. During the 15-day storage at $12 \pm 1^{\circ} \mathrm{C}$, a decrease in the value of the $\mathrm{L}^{*}$ parameter was observed, which is a naturally occurring process in tomatoes and has been verified by several studies conducted by, inter alia, Chen et al. [57] and Boonsiriwit et al. [58]. During storage, the $a^{*}$ parameter increased and the $b^{*}$ parameter decreased in all groups of tomatoes, regardless of the time of ozonisation and gas concentration. These changes were observed to a lesser extent during storage, which suggests that the fruit quality after storage remains acceptable. If the reduction in the $\mathrm{L}^{*}$ parameter (tomato darkening) during storage is too rapid, this would indicate poor storage conditions and a rapid deterioration process. Statistical analysis showed that the colour of the control samples did not differ significantly 
$(p \leq 0.05)$ during storage from the ozone treated samples, indicating that the ozonisation time and gas dose $\left(0.9\right.$ and $2.5 \mathrm{mg} \mathrm{L}^{-1} ; 30$ and $120 \mathrm{~min}$ ) did not change the colour of the surface of Rapanui tomatoes. The lack of a significant effect of ozone on the colour was previously demonstrated by the work of Glowacz and Ress [43], where exposure to ozone at a concentration of 0.45 and $0.9 \mu \mathrm{mol} \mathrm{mol}^{-1}$ had no effect on the colour of red chilli peppers. Research conducted by Rodoni et al. [56] also showed that ozone $\left(10 \mu \mathrm{L} \mathrm{L}^{-1}, 10 \mathrm{~min}\right)$ did not change the colour of tomatoes. The low doses of ozone did not damage the epidermis and appeared to have no negative impact on the quality of these fruit or vegetables.

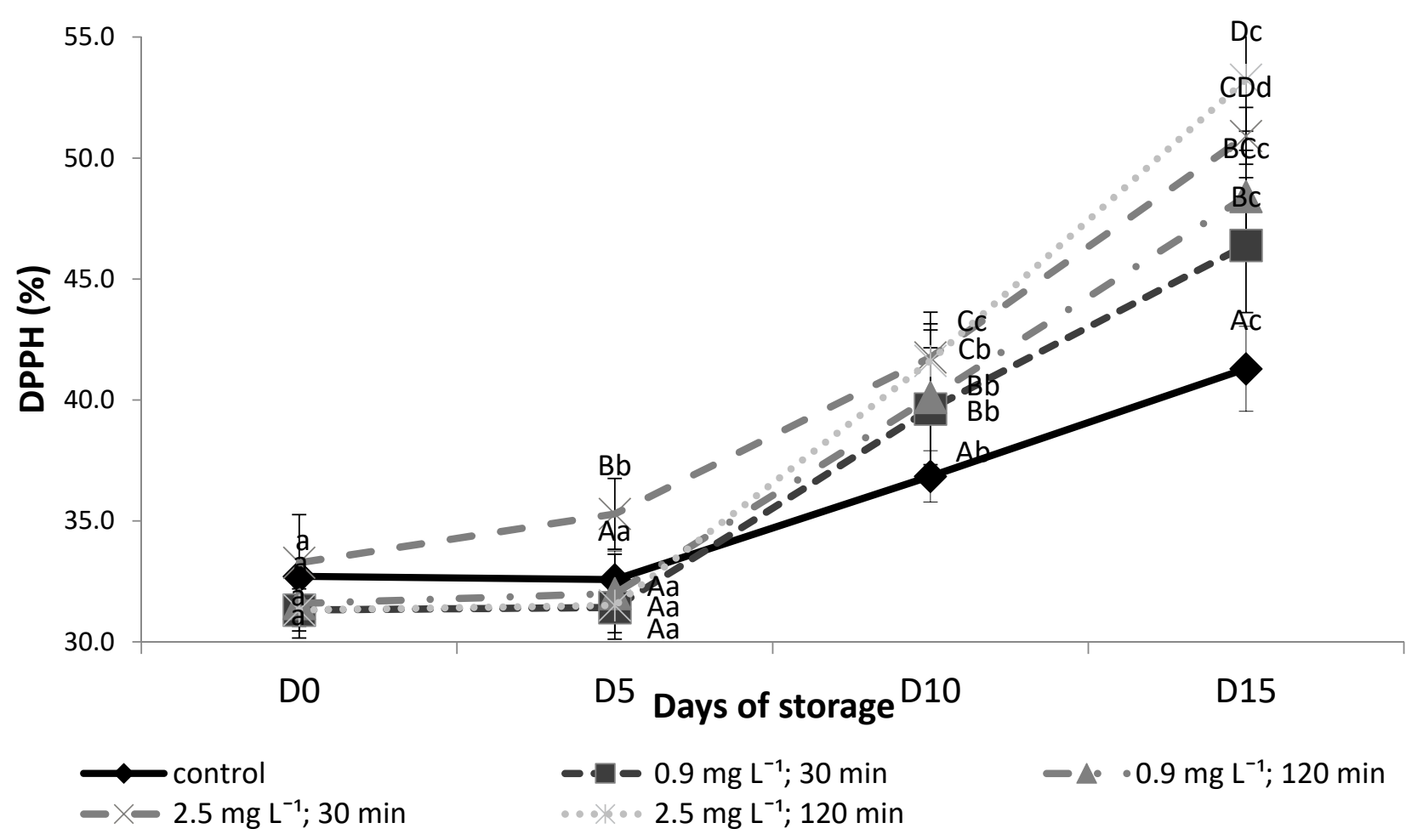

Figure 1. Impact of ozone concentration and storage on the total antioxidant activity (\% DPPH) of Rapanui tomatoes measured on $0,5,10$ and 15 days of storage. a-d-lowercase letters show significant differences for each treatment during storage time, A-D—capital letters show significant differences between treatments within each storage time. The values represented the mean \pm standard error.

Table 3. Impact of the ozone concentration and storage time on the colour $\mathrm{L}^{*}, \mathrm{a}^{*}, \mathrm{~b}^{*}$ of tomato cultivars of Rapanui tomatoes measured on $0,5,10$ and 15 days of storage.

\begin{tabular}{|c|c|c|c|c|}
\hline Group & Days in Storage & $L^{*}$ & $a^{*}$ & $\mathbf{b}^{*}$ \\
\hline \multirow{4}{*}{ Control } & 0 & $44.40^{\mathrm{d}} \pm 1.06$ & $25.56^{\mathrm{ABa}} \pm 1.05$ & $20.22^{c} \pm 0.65$ \\
\hline & 5 & $42.01^{\mathrm{c}} \pm 1.69$ & $27.64^{b} \pm 0.53$ & $18.32^{b} \pm 0.63$ \\
\hline & 10 & $38.81^{b} \pm 1.65$ & $28.71^{\mathrm{BCc}} \pm 0.80$ & $18.34^{\mathrm{Cb}} \pm 0.52$ \\
\hline & 15 & $36.83^{\mathrm{ABa}} \pm 0.62$ & $30.32^{\mathrm{Bd}} \pm 0.75$ & $16.96^{\mathrm{Ba}} \pm 0.42$ \\
\hline \multirow{4}{*}{$0.9 \mathrm{mg} \mathrm{L}^{-1} ; 30 \mathrm{~min}$} & 0 & $43.75^{c} \pm 1.34$ & $25.91^{\mathrm{Ba}} \pm 0.56$ & $21.09^{c} \pm 0.77$ \\
\hline & 5 & $42.49^{\mathrm{c}} \pm 1.51$ & $27.28^{\mathrm{b}} \pm 0.71$ & $18.17^{b} \pm 0.50$ \\
\hline & 10 & $39.08^{b} \pm 1.07$ & $28.35^{\mathrm{ABC} C} \pm 0.63$ & $17.90^{\mathrm{BCb}} \pm 0.42$ \\
\hline & 15 & $36.22^{\mathrm{Aa}} \pm 0.62$ & $29.61^{\mathrm{ABd}} \pm 1.03$ & $16.20^{\mathrm{Aa}} \pm 0.50$ \\
\hline \multirow{4}{*}{$0.9 \mathrm{mg} \mathrm{L}^{-1} ; 120 \mathrm{~min}$} & 0 & $44.23^{\mathrm{d}} \pm 1.48$ & $25.52^{\mathrm{ABa}} \pm 0.72$ & $20.69^{d} \pm 0.66$ \\
\hline & 5 & $42.21^{\mathrm{c}} \pm 1.74$ & $27.28^{b} \pm 0.74$ & $18.35^{\mathrm{c}} \pm 0.58$ \\
\hline & 10 & $39.18^{b} \pm 1.17$ & $27.81^{\mathrm{ABb}} \pm 0.66$ & $17.51^{\mathrm{Bb}} \pm 0.47$ \\
\hline & 15 & $36.35^{\mathrm{ABa}} \pm 0.91$ & $29.33^{\mathrm{ABc}} \pm 0.85$ & $16.04^{\mathrm{Aa}} \pm 0.41$ \\
\hline
\end{tabular}


Table 3. Cont.

\begin{tabular}{|c|c|c|c|c|}
\hline Group & Days in Storage & $\mathbf{L}^{*}$ & $a^{*}$ & $\mathbf{b}^{*}$ \\
\hline \multirow{4}{*}{$2.5 \mathrm{mg} \mathrm{L}^{-1} ; 30 \mathrm{~min}$} & 0 & $45.03^{c} \pm 1.63$ & $25.42^{\mathrm{ABa}} \pm 0.79$ & $20.57^{c} \pm 0.70$ \\
\hline & 5 & $42.37^{b} \pm 1.28$ & $27.06^{\mathrm{b}} \pm 0.46$ & $18.79^{b} \pm 0.50$ \\
\hline & 10 & $38.52^{\mathrm{a}} \pm 0.62$ & $27.53^{\mathrm{Ab}} \pm 0.90$ & $16.79^{\mathrm{Aa}} \pm 0.44$ \\
\hline & 15 & $37.38^{\mathrm{Ba}} \pm 1.17$ & $29.31^{\mathrm{ABc}} \pm 0.96$ & $16.58^{\mathrm{ABa}} \pm 0.72$ \\
\hline \multirow{4}{*}{$2.5 \mathrm{mg} \mathrm{L}^{-1} ; 120 \mathrm{~min}$} & 0 & $44.34^{\mathrm{c}} \pm 1.95$ & $24.68^{\mathrm{Aa}} \pm 0.86$ & $20.86^{c} \pm 0.89$ \\
\hline & 5 & $41.88^{b} \pm 1.76$ & $27.57^{b} \pm 0.87$ & $18.19^{b} \pm 0.34$ \\
\hline & 10 & $38.58^{a} \pm 0.80$ & $29.25^{\mathrm{Cc}} \pm 0.53$ & $17.87^{\mathrm{BCb}} \pm 0.62$ \\
\hline & 15 & $37.10^{\mathrm{ABa}} \pm 0.60$ & $29.05^{\mathrm{Ac}} \pm 0.69$ & $16.41^{\mathrm{ABa}} \pm 0.60$ \\
\hline
\end{tabular}

a-d-lowercase letters show significant differences for each treatment during storage time, A-C—capital letters show significant differences between treatments within each storage time. The values represented the mean \pm standard error.

\subsection{Firmness}

Loss of firmness during storage is a serious problem because it reduces marketability of the product due to reduced attractiveness to the market. Firmness of tomato fruit strongly influences the purchase decision and consumer's acceptance. It also influences the perception of taste, aroma, the shelf life and the transportation resilience of fruits [59].

Tomato storage in an atmosphere with 0.9 and $2.5 \mathrm{mg} \mathrm{L}^{-1}$ ozone for 30 and $120 \mathrm{~min}$ contributed to a statistically significant $(p \leq 0.05)$ difference in firmness, as compared to the non-ozone treated control group (Figure 2). With increased storage time, the firmness decreased in all the groups, which was likely related to loss of water and the activity of enzymes that degrade cell walls [60]. The cell wall matrices, especially pectin, are broken down during the ripening of fruits and vegetables, which reduces their firmness. It appears that the presence of ozone in the storage atmosphere may limit the loss of firmness during storage. The ozone treated groups exhibited higher firmness at D5, D10 and D15 compared with the control group. In the $c_{1} t_{2}$ and $c_{2} t_{1}$ groups, the decrease in firmness was most effectively reduced and at D15 the tomatoes lost only $26.2-27.0 \%$ of their firmness compared to D0. The greatest decrease in firmness was recorded in the control group at D15 (32.57\%). Similar results were recorded by Tzortzakis et al. [44] studies, who showed that exposure to ozone at a concentration of $1.0 \mu \mathrm{mol} \mathrm{mol}^{-1}$ significantly influenced the firmness of tomatoes of the Carousel cultivar during 12 days of storage (at $13{ }^{\circ} \mathrm{C}, \mathrm{RH} 95 \%$ ). In addition, Radoni et al. [56] demonstrated that exposing tomatoes to gaseous ozone at a concentration of $10 \mu \mathrm{L} \mathrm{L}^{-1}$ for 10 min has a statistically significant $(p \leq 0.05)$ effect on the preservation of their firmness.

\subsection{Assessment of Tomatoes Weight Losses during Storage}

According to García et al. [61], tomatoes are susceptible to rapid water loss, which results in weight loss, depending on the sensibility of the thin skin to damage. Changes in the weight of Rapanui tomatoes during storage are presented in Figure 3.

The weight of the ozone treated tomatoes at D5, D10 and D15 was not drastically different from their weight at D0, suggesting that ozone may efficiently reduce weight loss during storage of treated tomatoes in comparison with the control group. The greatest weight loss was recorded in the control group, where the mass was reduced by as much as $4.30 \%$ while in the groups of tomatoes subjected to ozonisation, the average weight loss was $3.37 \%$. Ozonisation of tomatoes for $120 \mathrm{~min}$ at an ozone concentration of $2.5 \mathrm{mg} \mathrm{L}^{-1}$ (group $\mathrm{c}_{2} \mathrm{t}_{2}$ ) resulted in weight loss of $3.02 \%$ at D15. Ozonisation effectively reduced weight loss in Rapanui tomatoes over the entire period of storage. 


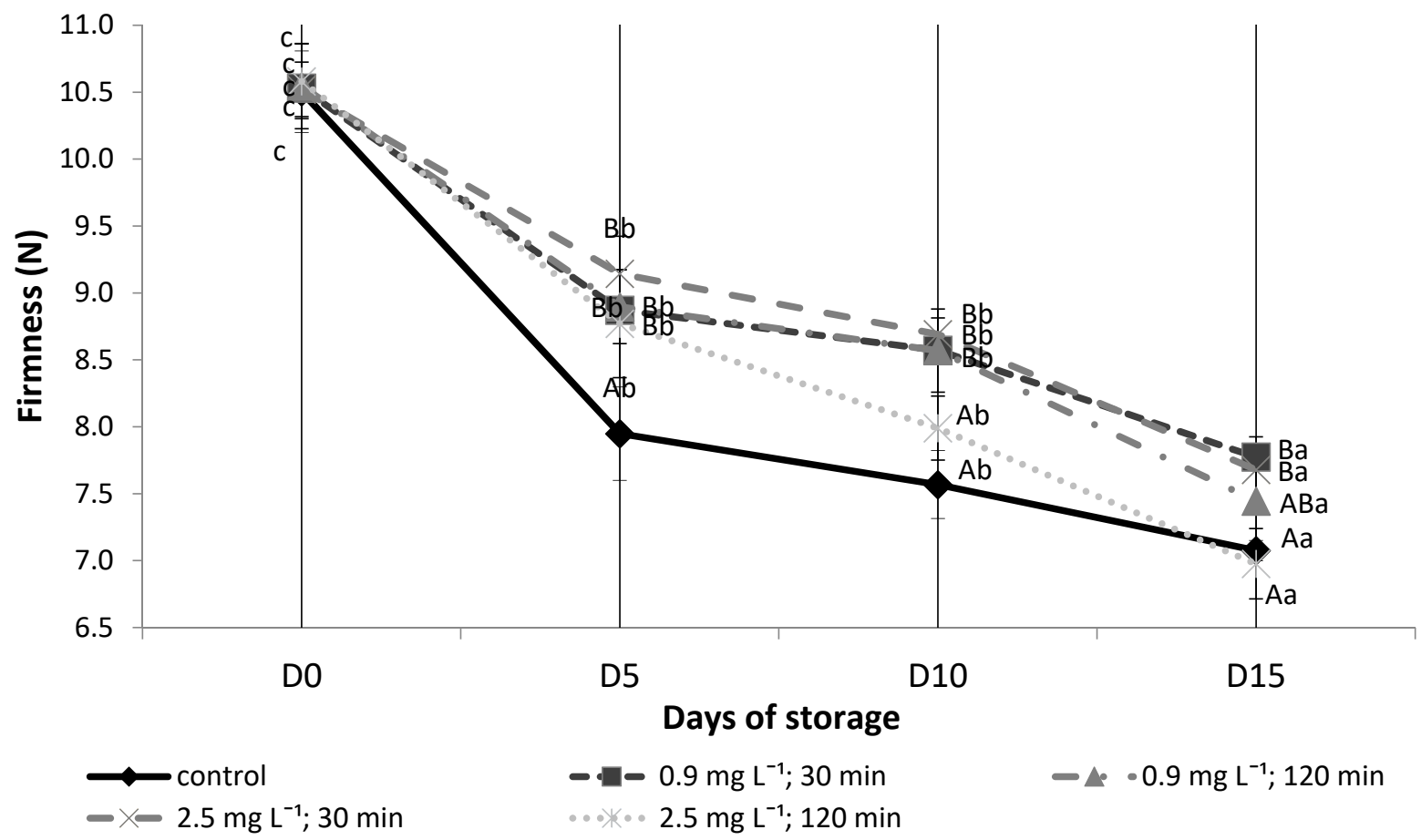

Figure 2. Impact of ozone concentration, ozonisation time and storage on the firmness $(\mathrm{N})$ of Rapanui tomatoes measured at $0,5,10$, and 15 days of storage. a-c-lowercase letters show significant differences for each treatment during storage time, A-B - capital letters show significant differences between treatments within each storage time. The values represented the mean \pm standard error.

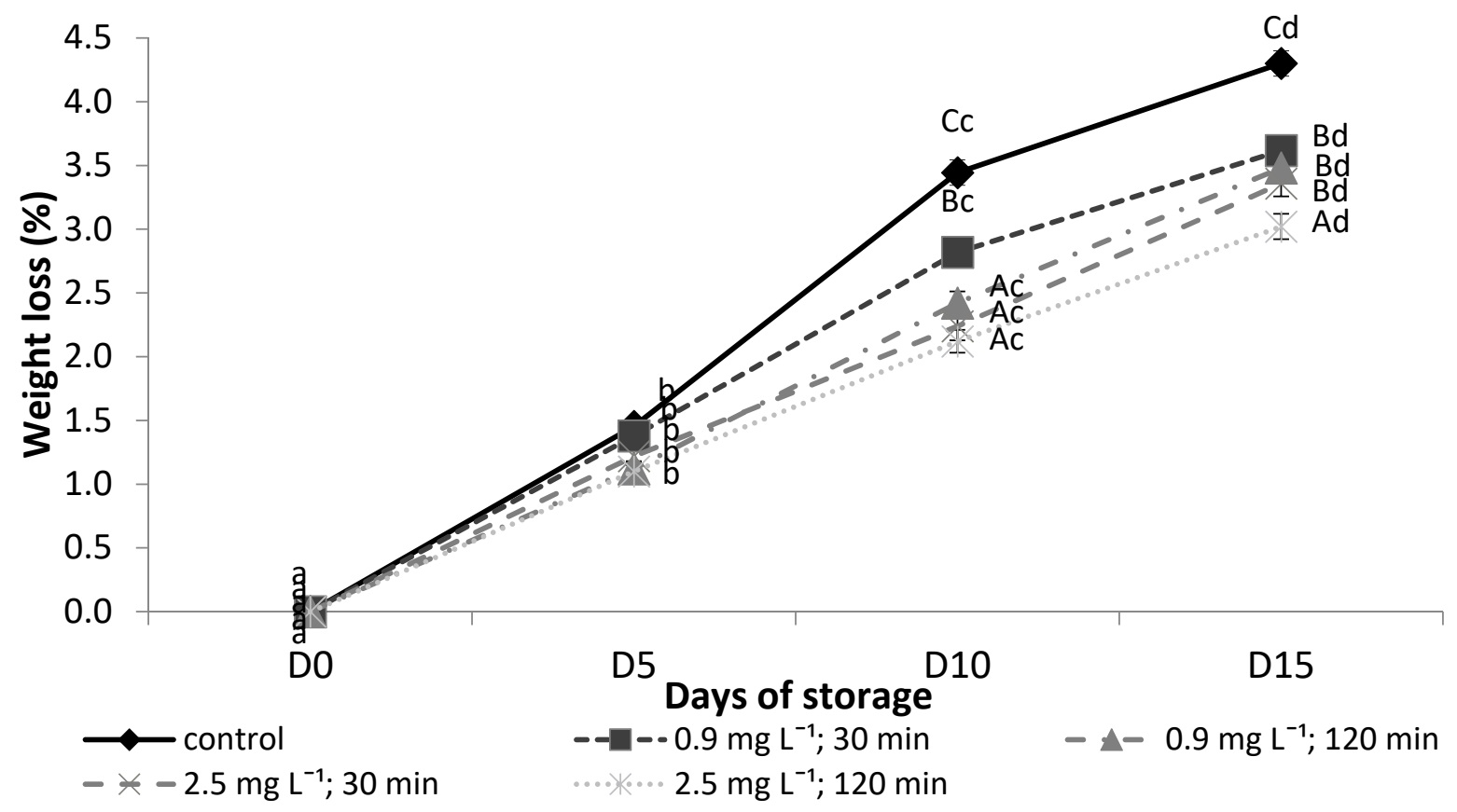

Figure 3. Weight loss (\%) Rapanui tomatoes stored at $12 \pm 1{ }^{\circ} \mathrm{C}$ measured on $0,5,10$ and 15 days of storage. a-d-lowercase letters show significant differences for each treatment during storage time, $\mathrm{A}-\mathrm{C}$-capital letters show significant differences between treatments within each storage time. The values represented the mean \pm standard error.

These results were in agreement with studies carried out by Glowacz and Rees [43], where the impact of the ozone dose on the weight loss of red pepper was investigated. Ozone at concentrations of 0.9 and $2.0 \mu \mathrm{mol} \mathrm{mol}^{-1}$ resulted in a statistically significant 
$(p<0.05)$ reduction of weight loss in comparison to the non-ozonised group. Slightly differ-ent results were reported by Tzortzakis et al. [44], who saw no impact of ozonisation $\left(1.0 \mu \mathrm{mol} \mathrm{mol}{ }^{-1}\right)$ on the weight loss of Carousel tomatoes during storage at $13^{\circ} \mathrm{C}$.

The storage conditions had a great impact on the storage time, which is also evident from research carried out by Javanmardi and Kubota [17]. Clermon tomatoes stored at $12{ }^{\circ} \mathrm{C}$ for the first 7 days and then $5{ }^{\circ} \mathrm{C}$ for the next 7 days exhibited a statistically significant $(p<0.01)$ reduction in weight loss compared with tomatoes stored at room temperature $\left(25-27^{\circ} \mathrm{C}\right)$ after a storage time of 7 days. This is in agreement with Park et al. [48], who investigated the relationship between weight loss and storage time at 8,12 and $20^{\circ} \mathrm{C}$.

We concluded that ozone doses of $0.9 \mathrm{mg} \mathrm{L}^{-1}$ and $2.5 \mathrm{mg} \mathrm{L}^{-1}$ at ozonisation times of $30 \mathrm{~min}$ and $120 \mathrm{~min}$, combined with storage at $12 \pm 1^{\circ} \mathrm{C}$, reduced tomato weight loss during 15 days of storage.

\subsection{Microbiological Analysis (Yeasts and Moulds)}

Determination of the total amount of yeasts and moulds according to standard PNISO 7954:1999 enables testing of the impact of ozonisation on the microbiological safety of red Rapanui cultivar tomatoes. Results of these analyses are presented in Figure 4 . The total amount of yeasts and moulds in the control group was $1.15 \log _{10} \mathrm{CFU} \mathrm{g}^{-1}$, while in ozonised groups as early as at D0, a lower microbial content was observed. The lowest total amount of yeast and moulds at D0 $\left(0.90 \log _{10} \mathrm{CFU} \mathrm{g}{ }^{-1}\right)$ was recorded in tomatoes ozonised with a dose of $2.5 \mathrm{mg} \mathrm{L}^{-1}$. During storage, a significant increase in the number of microorganisms in each group was recorded, but tomatoes from the control group exhib-ited the highest amount of colony forming yeasts and moulds $\left(4.84 \log _{10} \mathrm{CFU} \mathrm{g}{ }^{-1}\right.$ at D15). Ozone therefore caused an evident reduction in yeast and mould content, but the most effective dose was $2.5 \mathrm{mg} \mathrm{L}^{-1}$ with an ozonisation time of $120 \mathrm{~min}\left(\mathrm{c}_{2} \mathrm{t}_{2}\right)$.

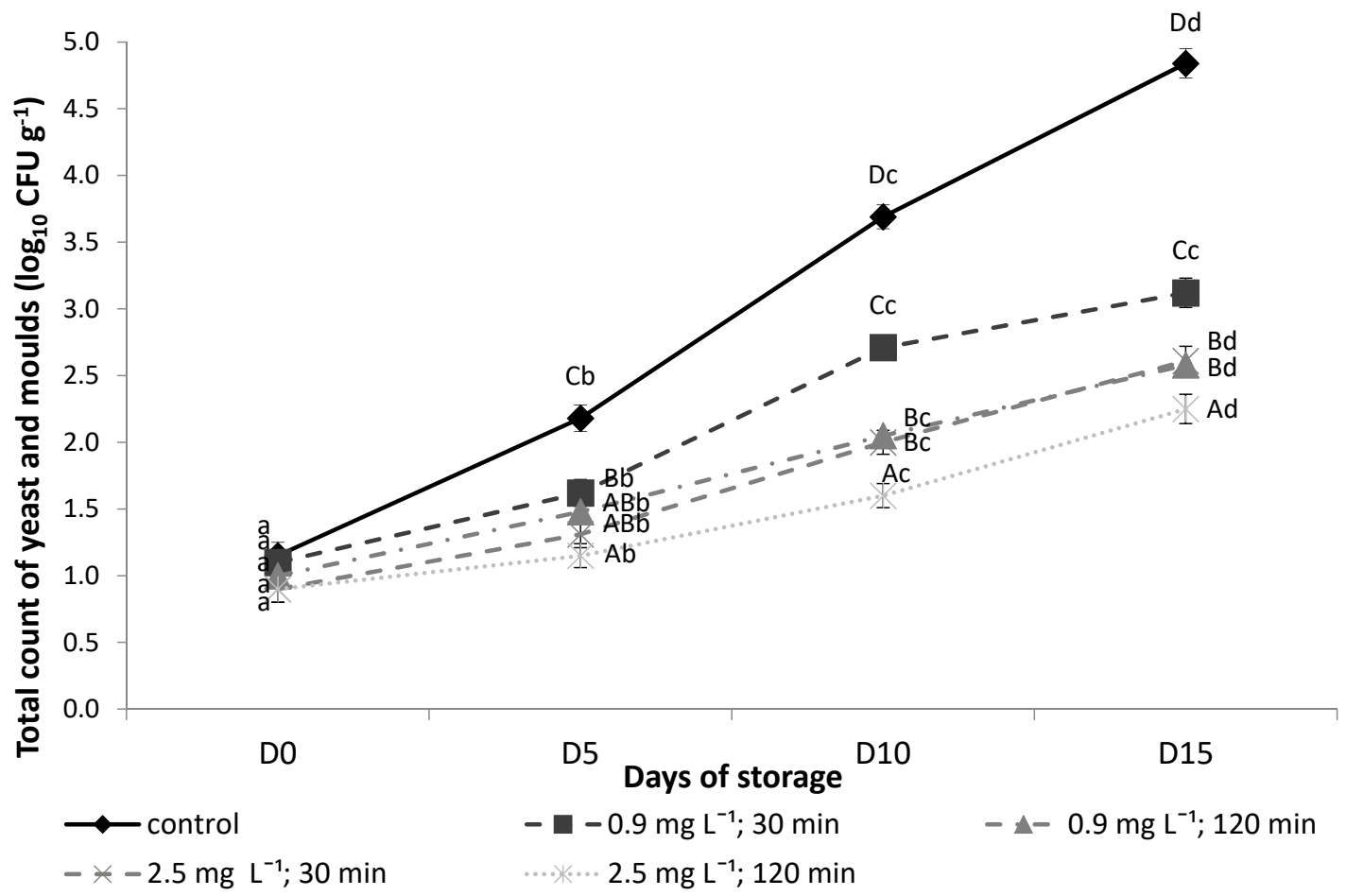

Figure 4. Total count of yeast and moulds $\left(\log _{10} \mathrm{CFU} \mathrm{g}{ }^{-1}\right)$ Rapanui tomatoes stored at $12 \pm 1{ }^{\circ} \mathrm{C}$ measured at 0,5 , 10 and 15 days of storage. a-d-lowercase letters show significant differences for each treatment during storage time, A-D—capital letters show significant differences between treatments within each storage time. The values represented the mean \pm standard error. 
Tzortzaki et al. [44] ozonised tomatoes with a dose of 0.005 to $5.0 \mu \mathrm{mol} \mathrm{mol}^{-1}$ and demonstrated that this gas efficiently suppressed growth of the pathogen B. cinerea on the fruit surface. Analyses also confirmed that higher ozone concentration and longer exposure time caused more effective reduction of microorganisms growth on the surface of tomatoes during storage. Similar conclusions were drawn by Aguayo et al. [23] who cyclically ozonised tomatoes cultivar Thomas at an ozone concentration of $7 \mu \mathrm{L} \mathrm{L}^{-1}$ for 30 min every $3 \mathrm{~h}$. Ozonisation inhibited the expansion of yeast and moulds during the 15-day storage. Wani et al. [62] previously suggested that efficiency of ozonisation depends not only on the type of microorganism, but also the age of a colony, as older colonies are more resistant to ozone, which may be related to their stronger attachment to the product. Ozone reacts with organic compounds, causing oxidation and rapid degradation of the cell wall of microorganisms, especially during the first stage of ozone activity. Subsequently, polyunsaturated fatty acid which comprise the cytoplasmic membrane are peroxidised, which leads to formation of peroxides of these compounds. Peroxidation product changes the physical properties of cell membranes and the activity of micro-organisms becomes inhibited. In conclusion, ozone effectively inhibits growth of yeast and moulds on the surface of tomatoes.

\section{Conclusions}

Storage of tomatoes in atmosphere that has ozone at concentrations of 0.9 or $2.5 \mathrm{mg} \mathrm{L}^{-1}$ and for durations of 30 or 120 min proved to be a factor causing an increase in the content of total soluble solids and a reduction in titratable acidity. Our results show that treatment of tomatoes with ozone at a concentration of $2.5 \mathrm{mg} \mathrm{L}^{-1}$ for 120 min produces the best results. Treatment with ozone was also favourable for the maintenance of the total flavonoid, lycopene and total carotenoid content and total antioxidant activity. The most effective preservation was seen in tomatoes from group $\mathrm{c}_{1} \mathrm{t}_{2}\left(0.9 \mathrm{mg} \mathrm{L}^{-1}, 120 \mathrm{~min}\right)$. Exposure of tomatoes to the ozonisation process under refrigerated conditions resulted in efficient inactivation of microorganisms which are located on the fruit surface, which enables reduction of fruit weight loss with simultaneous maintenance of high fruit quality. Application of ozone inhibited yeasts and moulds growth on the surface of tomatoes and limited weight loss, without negatively affect their firmness or colour stability. Outcomes of this research show that ozone may be used as an alternative disinfecting technology in the fresh tomatoes branch, which does not cause deterioration of the nutritive quality and the physical properties of tomatoes.

Author Contributions: For conceptualization, A.O.; methodology, A.O. and A.S.; software, A.S.; validation, A.W., formal analysis, A.P.; investigation, A.O. and I.W.-K.; data curation, A.O. and A.S.; writing—original draft preparation, A.O.; writing—review and editing, A.O., A.P.; visualization, A.W. All authors have contributed equally to the development of this article. All authors have read and agreed to the published version of the manuscript.

Funding: This research was financed by the Polish Ministry of Science and Higher Education through funds provided to the Institute of Human Nutrition Sciences, Warsaw University of Life Sciences (WULS) for scientific research.

Institutional Review Board Statement: Not applicable.

Informed Consent Statement: Not applicable.

Data Availability Statement: The data presented in this study are available on request from the corresponding author.

Conflicts of Interest: The authors declare no conflict of interest. 


\section{References}

1. Bakir, S.; Capanoglu, E.; Hall, R.D.; de Vos, R.C.H. Variation in secondary metabolites in a unique set of tomato accessions collected in Turkey. Food Chem. 2020, 317, 126406. [CrossRef] [PubMed]

2. Demiray, E.; Tulek, Y.; Yilmaz, Y. Degradation kinetics of lycopene, b-carotene and ascorbic acid in tomatoes during hot air drying. LWT-Food Sci. Technol. 2013, 50, 172-176. [CrossRef]

3. Ilahy, R.; Hdider, C.; Lenucci, M.S.; Tlili, I.; Dalessandro, G. Phytochemical composition and antioxidant activity of high-lycopene tomato (Solanum lycopersicum L.) cultivars grown in Southern Italy. Sci. Hortic. 2011, 127, 255-261. [CrossRef]

4. Choi, S.H.; Kim, D.S.; Kozukue, N.; Kim, H.J.; Nishitani, Y.; Mizuno, M.; Levin, C.E.; Friedman, M. Protein, free amino acid, phenolic, $\beta$-carotene, and lycopene content, and antioxidative and cancer cell inhibitory effects of 12 greenhouse-grown commercial cherry tomato varieties. J. Food Compos. Anal. 2014, 34, 115-127. [CrossRef]

5. Xu, S.; Sun, X.; Lu, H.; Yang, H.; Ruan, Q.; Huang, H.; Chen, M. Detecting and monitoring the flavor of tomato (Solanum lycopersicum) under the impact of postharvest handlings by physicochemical parameters and electronic nose. Sensors 2018, 18, 1847. [CrossRef] [PubMed]

6. Raiola, A.; Rigano, M.M.; Calafiore, R.; Frusciante, L.; Barone, A. Enhancing the human-promoting effects of tomato fruit for biofortified food. Mediat. Inflamm. 2014. [CrossRef] [PubMed]

7. Tanambell, H.; Quek, S.Y.; Bishop, K.S. Screening of in vitro health benefits of tangerine tomatoes. Antioxidants 2019, 8, 230. [CrossRef]

8. Szabo, K.; Diaconeasa, Z.; Cătoi, A.-F.; Vodnar, D.C. Screening of ten tomato varieties processing waste for bioactive components and their related antioxidant and antimicrobial activities. Antioxidants 2019, 8, 292. [CrossRef]

9. Giovannucci, E.; Ascherio, A.; Rimm, E.B.; Stampfer, M.J.; Colitz, G.A.; Willett, W.C. Intake of carotenoids and retinol in relation to risk of prostate cancer. J. Natl. Cancer Inst. 1995, 87, 1767-1776. [CrossRef]

10. Paur, I.; Lilleby, W.; Bohn, S.K.; Hulander, E.; Klein, W.; Vlatkovic, L.; Axcrona, K.; Bolstad, N.; Bjøro, T.; Laake, P.; et al. Tomato based randomized controlled trial in prostate cancer patients: Effect on PSA. Clin. Nutr. 2017, 36, 672-679. [CrossRef]

11. Giovannucci, E. Tomato base-products, lycopene and cancer. Review of epidemiologic literature. J. Natl. Cancer Inst. 1999, 91, 317-331. [CrossRef]

12. Giovannucci, E.; Rimm, E.B.; Liu, Y.; Stampfer, M.J.; Willett, W.C. A prospective study of tomato products, lycopene, and prostate cancer risk. J. Natl. Cancer Inst. 2002, 94, 391-398. [CrossRef]

13. Ingallina, C.; Maccelli, A.; Spano, M.; Di Matteo, G.; Di Sotto, A.; Giusti, A.M.; Vinci, G.; Di Giacomo, S.; Rapa, M.; Ciano, S.; et al. Chemico-biological characterization of Torpedino Di Fondi ${ }^{\circledR}$ tomato fruits: A comparison with San Marzano Cultivar at two ripeness stages. Antioxidants 2020, 9, 1027. [CrossRef]

14. Sumalan, R.M.; Ciulca, S.I.; Poiana, M.A.; Moigradean, D.; Radulov, I.; Negrea, M.; Crisan, M.E.; Copolovici, L.; Sumalan, R.L. The antioxidant profile evaluation of some tomato Landraces with soil salinity tolerance correlated with high nutraceuticaland functional value. Agronomy 2020, 10, 500. [CrossRef]

15. Domínguez, R.; Gullón, P.; Pateiro, M.; Munekata, P.E.S.; Zhang, W.; Lorenzo, J.M. Tomato as potential source of natural additives for meat industry. A review. Antioxidants 2020, 9, 73. [CrossRef] [PubMed]

16. Kabir, M.S.N.; Ali, M.; Lee, W.H.; Cho, S.I.; Chung, S.O. Physicochemical quality changes in tomatoes during delayed cooling and storage in a controlled chamber. Agriculture 2020, 10, 196. [CrossRef]

17. Javanmardi, J.; Kubota, C. Variation of lycopene, antioxidant activity, total soluble solids and weight loss of tomato during postharvest storage. Postharvest Biol. Technol. 2006, 41, 151-155. [CrossRef]

18. Sachadyn-Król, M.; Materska, M.; Chilczuk, B. Ozonation of hot red pepper fruits increases their antioxidant activity and changes some antioxidant contents. Antioxidants 2019, 8, 356. [CrossRef] [PubMed]

19. Marchica, A.; Cotrozzi, L.; Detti, R.; Lorenzini, G.; Pellegrini, E.; Petersen, M.; Nali, C. The biosynthesis of phenolic compounds is an integrated defence mechanism to prevent ozone injury in salvia officinalis. Antioxidants 2020, 9, 1274. [CrossRef]

20. Matłok, N.; Piechowiak, T.; Zardzewiały, M.; Gorzelany, J.; Balawejder, M. Effects of ozone treatment on microbial status and the contents of selected bioactive compounds in Origanum majorana L. plants. Plants 2020, 9, 1637. [CrossRef]

21. Zhu, X.; Jiang, J.; Yin, C.; Li, G.; Jiang, Y.; Shan, Y. Effect of ozone treatment on flavonoid accumulation of Satsuma mandarin (Citrus unshiu Marc.) during ambient storage. Biomolecules 2019, 9, 821. [CrossRef]

22. Zardzewiały, M.; Matlok, N.; Piechowiak, T.; Gorzelany, J.; Balawejder, M. Ozone treatment as a process of quality improvement method of Rhubarb (Rheum rhaponticum L.) petioles during storage. Appl. Sci. 2020, 10, 8282. [CrossRef]

23. Aguayo, E.; Escalona, V.; Silveira, A.C.; Artés, F. Quality of tomato slices disinfected with ozonated water. Food Sci. Technol. Int. 2013, 20, 227-235. [CrossRef]

24. Ilahy, R.; Hdider, C.; Lenucci, M.S.; Tlili, I.; Dalessandro, G. Antioxidant activity and bioactive compound changes during fruit ripening of high-lycopene tomato cultivars. J. Food Compos. Anal. 2011, 24, 588-595. [CrossRef]

25. Lee, H.S. Characterization of carotenoids in juice of red navel orange (Cara Cara). J. Agric. Food Chem. 2001, 49, 2563-2568. [CrossRef]

26. Fish, W.W.; Perkins-Veazie, P.; Collins, J.K. A quantitative assay for lycopene that utilizes reduced volumes of organic solvent. J. Food Compos. Anal. 2002, 15, 309-317. [CrossRef] 
27. Onopiuk, A.; Półtorak, A.; Wyrwisz, J.; Moczkowska, M.; Stelmasiak, A.; Lipińska, A.; Szpicer, A.; Zalewska, M.; Zaremba, R.; Kubon, M.; et al. Impact of ozonisation on pro-health properties and antioxidant capacity of 'Honeoye' strawberry fruit. CyTA-J. Food 2017, 15, 58-64.

28. Lu, C.; Ding, J.; Park, H.K.; Feng, H. High intensity ultrasound as a physical elicitor affects secondary metabolites and antioxidant capacity of tomato fruits. Food Control 2020, 113, 107176. [CrossRef]

29. Mauro, R.P.; Agnello, M.; Onofri, A.; Leonardi, C.; Giuffrida, F. Scion and rootstock differently influence growth, yield and quality characteristics of cherry tomato. Plants 2020, 9, 1725. [CrossRef]

30. Aragüez, L.; Colombo, A.; Borneo, R.; Aguirre, A. Active packaging from triticale flour films for prolonging storage life of cherry tomato. Food Packag. Shelf Life 2020, 25, 100520. [CrossRef]

31. Onopiuk, A.; Półtorak, A.; Moczkowska, M.; Szpicer, A.; Wierzbicka, A. The impact of ozone on health-promoting, microbiological and colour properties of Rubus ideaus raspberries. CyTA-J. Food. 2017, 15, 563-573. [CrossRef]

32. López-Palestina, C.U.; Aguirre-Mancilla, C.L.; Raya-Pérez, J.C.; Ramírez-Pimentel, J.G.; Gutiérrez-Tlahque, J.; Hernández-Fuentes, A.D. The effect of an edible coating with tomato oily extract on the physicochemical and antioxidant properties of garambullo (Myrtillocactus geometrizans) fruits. Agronomy 2018, 8, 248. [CrossRef]

33. Petropoulos, S.A.; Fernandes, Â.; Xyrafis, E.; Polyzos, N.; Antoniadis, V.; Barros, L.; Ferreira, I.C.F.R. The optimization of nitrogen fertilization regulates crop performance and quality of processing tomato (Solanum lycopersicum L. cv. Heinz 3402). Agronomy 2020, 10, 715. [CrossRef]

34. Inestroza-Lizardo, C.; Mattiuz, B.H.; da Silva, J.P.; Galati, V.C.; Voigt, V. Hyperbaric pressure at room temperature increases post-harvest preservation of the tomato cultivar 'Débora'. Sci. Hortic. 2018, 228, 103-112. [CrossRef]

35. Liu, L.H.; Zabaras, D.; Bennett, L.E.; Aguas, P.; Woonton, B.W. Effects of UV-C, red light and sun light on the carotenoid content and physical qualities of tomatoes during post-harvest storage. Food Chem. 2009, 115, 495-500. [CrossRef]

36. Odriozola-Serrano, J.; Soliva-Fortuny, R.; Martin-Bellono, O. Effect of minimal processing on bioactive compounds and colour attributes of fresh-cut tomatoes. LWT-Food Sci. Technol. 2008, 41, 217-226. [CrossRef]

37. Zou, J.; Chen, J.; Tang, N.; Gao, Y.; Hong, M.; Wei, W.; Cao, H.; Jian, W.; Li, N.; Deng, W.; et al. Transcriptome analysis of aroma volatile metabolism change in tomato (Solanum lycopersicum) fruit under different storage temperatures and 1-MCP treatment. Postharvest Biol. Technol. 2018, 135, 57-67. [CrossRef]

38. Buendía-Moreno, L.; Soto-Jover, S.; Ros-Chumillas, M.; Antolinos, V.; Navarro-Segura, L.; Sánchez-Martínez, M.J.; MartínezHernández, G.B.; López-Gómez, A. Innovative cardboard active packaging with a coating including encapsulated essential oils to extend cherry tomato shelf life. LWT-Food Sci. Technol. 2019, 116, 108584. [CrossRef]

39. Tigist, A.; Workneh, T.S.; Woldetsadik, K. Effects of variety on the quality of tomato stored under ambient conditions. J. Food Sci. Technol. 2011, 50, 477-486. [CrossRef] [PubMed]

40. Bravo, S.; García-Alonso, J.; Martín-Pozuelo, G.; Gomez, V.; Santaella, M.; Navarro-Gonzalez, I.; Periago, M.J. The influence of post-harvest UV-C hormesis on lycopene, b-carotene, and phenolic content and antioxidant activity of breaker tomatoes. Food Res. 2012, 49, 296-302. [CrossRef]

41. Del Giudice, R.; Raiola, A.; Tenore, G.; Frusciante, L.; Barone, A.; Monti, D.M.; Rigano, M.M. Antioxidant bioactive compounds in tomato fruits at different ripening stages and their effects on normal and cancer cells. J. Funct. Foods 2015, 18, 83-94. [CrossRef]

42. Ding, X.X.; Guo, Y.; Ni, Y.N.; Kokot, S.A. Novel NIR spectroscopic method for rapid analyses of lycopene, total acid, sugar, phenols and antioxidant activity in dehydrated tomato samples. Vib. Spectrosc. 2016, 82, 1-9. [CrossRef]

43. Glowacz, M.; Rees, D. Exposure to ozone reduces postharvest quality loss in red and green chilli peppers. Food Chem. 2016, 210, 305-310. [CrossRef]

44. Tzortzakis, N.; Borland, A.; Singleton, I.; Barnes, J. Impact of atmospheric ozone-enrichment on quality-related attributes of tomato fruit. Postharvest Biol. Technol. 2007, 45, 317-325. [CrossRef]

45. Gonzali, S.; Perata, P. Anthocyanins from purple tomatoes as novel antioxidants to promote human health. Antioxidants 2020, 9, 1017. [CrossRef]

46. Onopiuk, A.; Półtorak, A.; Wojtasik-Kalinowska, I.; Szpicer, A.; Marcinkowska-Lesiak, M.; Pogorzelski, G.; Wierzbicka, A. Impact of the storage atmosphere enriched with ozone on the quality of Lycopersicon esculentum tomatoes. J. Food Process. Pres. 2019, 43, e14252. [CrossRef]

47. Klunklin, W.; Savage, G. Effect on quality characteristics of tomatoes grown under well-watered and drought stress conditions. Foods 2017, 6, 56. [CrossRef]

48. Park, M.H.; Sangwanangkul, P.; Baek, D.R. Changes in carotenoid and chlorophyll content of black tomatoes (Lycopersicone sculentum L.) during storage at various temperatures. Saudi J. Biol. Sci. 2018, 25, 57-65. [CrossRef] [PubMed]

49. Kopec, R.E.; Riedel, K.M.; Harrison, E.H.; Curley, R.W.; Hruszkewycz, D.P.; Clinton, S.K.; Schwartz, S.J. Identification and quantification of apo-lycopenals in fruits, vegetables and human plasma. J. Agric. Food Chem. 2010, 58, 3290-3296. [CrossRef] [PubMed]

50. Ölmez, H.; Akbas, M.Y. Optimization of ozone treatment of fresh-cut green leaf lettuce. J. Food Eng. 2009, 90, 487-494. [CrossRef]

51. Georgé, S.; Tourniaire, F.; Gautier, H.; Goupy, P.; Rock, E.; Caris-Veyrat, C. Changes in the contents of carotenoids, phenolic compounds and vitamin $\mathrm{C}$ during technical processing and lyophilisation of red and yellow tomatoes. Food Chem. 2011, 124, 1603-1611. [CrossRef] 
52. Pinela, J.; Barros, L.; Carvalho, A.M.; Ferreira, I.C. Nutritional composition and antioxidant activity of four tomato (Lycopersicon esculentum L.) farmer' varieties in Northeastern Portugal homegardens. Food Chem. Toxicol. 2012, 50, 829-834. [CrossRef] [PubMed]

53. Sérino, S.; Costagliola, G.; Gomez, L. Lyophilized tomato plant material: Validation of a reliable extraction method for the analysis of vitamin C. J. Food Compos. Anal. 2019, 81, 37-45. [CrossRef]

54. Dewanto, V.; Wu, X.; Adom, K.K.; Liu, R.H. Thermal processing enhances the nutritional value of tomatoes by increasing total antioxidant activity. J. Agric. Food Chem. 2002, 50, 3010-3014. [CrossRef]

55. Mirdehghan, S.H.; Valero, D. Bioactive compounds in tomato fruit and its antioxidant activity as affected by incorporation of aloe, eugenol, and thymol in fruit package during storage. Int. J. Food Prop. 2017, 20, 1798-1806.

56. Rodoni, L.; Casadei, N.; Concellon, A.; Alicia, A.R.C.; Vicente, A.R. Effect of short-term ozone treatments on tomato (Solanum lycopersicum L.) fruit quality and cell wall degradation. J. Agric. Food Chem. 2010, 58, 594-599.

57. Chen, H.; Zhang, Y.; Zhong, Q. Potential of acidified sodium benzoate as an alternative wash solution of cherry tomatoes: Changes of quality, background microbes, and inoculated pathogens during storage at 4 and $21^{\circ} \mathrm{C}$ post-washing. Food Microbiol. 2019, 82, 111-118. [CrossRef]

58. Boonsiriwit, A.; Xiao, Y.; Joung, J.; Kim, M.; Singh, S.; Lee, Y.S. Alkaline halloysite nanotubes/low density polyethylene nanocomposite films with increased ethylene absorption capacity: Applications in cherry tomato packaging. Food Packag. Shelf Life 2020, 25, 100533. [CrossRef]

59. Causse, M.; Friguet, C.; Coiret, C.; Lépicier, M.; Navez, B.; Lee, M.; Holthuysen, N.; Sinesio, F.; Moneta, E.; Grandillo, S. Consumer preferences for fresh tomato at the European scale: A common segmentation on taste and firmness. J. Food Sci. 2010, 75, S531-S541. [CrossRef] [PubMed]

60. Bertin, N.; Génard, M. Tomato quality as influenced by preharvest factors. Sci. Hortic. 2018, 233, 264-276. [CrossRef]

61. García, M.; Casariego, A.; Díaz, R.; Roblejo, L. Effect of edible chitosan/zeolite coating on tomatoes quality during refrigerated storage. Emir. J. Food Agric. 2014, 26, 238-246.

62. Wani, S.; Barnes, J.; Singleton, I. Investigation of potential reasons for bacterial survival on 'ready-to-eat' leafy produce during exposure to gaseous ozone. Postharvest Biol. Technol. 2016, 111, 185-190. [CrossRef] 